\title{
Proteinase Inhibitor Gene
}

National Cancer Institute

\section{Source}

National Cancer Institute. Proteinase Inhibitor Gene. NCI Thesaurus. Code C29936.

Proteinase Inhibitor Genes encode Proteinase Inhibitor Proteins that block the activity of proteases, endopeptidases that catalyze the cleavage of internal peptide bonds in a polypeptide or protein substrate (Serine Endopeptidases, Cysteine Endopeptidases, Aspartic Endopeptidases, Metalloendopeptidases, and other Endopeptidases). ( $\mathrm{NCl}$ ) 